\title{
Plasmid Content of Streptococcus faecalis Strain 39-5 and Identification of a Pheromone (cPD1)-induced Surface Antigen
}

\author{
By Y. YAGI, $\uparrow$ R. E. KESSLER, J. H. SHAW, D. E. LOPATIN, F. AN AND \\ D. B. CLEWELL*
}

The Dental Research Institute and the Departments of Oral Biology and Microbiology, Schools of Dentistry and Medicine, The University of Michigan, Ann Artor, Michigan 48109, U.S.A.

(Received 20 July 1982; revised 5 September 1982)

\begin{abstract}
Streptococcus faecalis $39-5$ is a haemolytic, bacteriocinogenic strain harbouring six plasmids. One of these plasmids, pPD1 (36.4 MDal) determines a bacteriocin and encodes a conjugative response to the sex pheromone cPD1 excreted by recipient (plasmid-free) strains. The pheromone response is characterized by the formation of mating aggregates of donors (responders) with recipients. Aggregation required the presence of phosphate and divalent cations and was inhibited by agents or conditions that destroy protein structure. Aggregation was postulated to be due to synthesis of a new proteinaceous molecule on the donor cell surface. Referred to as 'aggregation substance', such a material was identified and found to exhibit antigenic properties not associated with uninduced cells; it could be detected by immunoelectron microscopy. Aggregation substance could be extracted from induced cells but not uninduced cells as demonstrated by crossed immunoelectrophoresis. Antibody raised against the aggregation substance controlled by pPD1 cross-reacted with aggregation substance determined by other plasmid systems which respond to pheromones unrelated to cPD1.
\end{abstract}

\section{INTRODUCTION}

Recent reports from our laboratory have dealt with pheromone-induced mating responses in Streptococcus faecalis (Dunny et al., 1978; Dunny et al., 1979; Clewell \& Brown, 1980; Clewell, 1981). Potential plasmid-free recipient cells excrete several low molecular weight, heat-stable substances which have been referred to as 'clumping inducing agents'. These clumping inducing agents induce donor strains harbouring certain conjugative plasmids to undergo a process involving protein synthesis that leads to the formation of mating aggregates. Once the plasmid is acquired by the recipient, the production of the related pheromone is shut off. Donors are induced to self-aggregate upon exposure to extracts containing clumping inducing agent. This self-clumping generally occurs within $45 \mathrm{~min}$ and is useful in quantifying the sex pheromones; a microtitre dilution assay was developed for this purpose (Dunny et al., 1979). It was proposed (Dunny et al., 1979) that induction resulted in the appearance of an adhesive 'aggregation substance' which interacts with a 'binding substance' present on the surface of recipients (and donors) to facilitate aggregation.

Streptococcus faecalis strain 39-5 was involved in many of the original experiments relating to the identification and behaviour of sex pheromones, and one of its plasmids, pPD1, was shown to be responsible for the mating (aggregation) response. Here we present a general characterization of the plasmid content of strain $39-5$ as well as a restriction map of pPD1. We also report the identification of a surface antigen whose appearance correlates with aggregation and which is assumed to represent aggregation substance controlled by pPD1. The data show that it is a proteinaceous substance whose activity requires the presence of phosphate and divalent cations. We also show that the aggregation substance induced in donors harbouring

† Present address: The Upjohn Company, Kalamazoo, Michigan 49001, U.S.A. 


\title{
Table 1. Strains of Streptococcus faecalis used in this study
}

\begin{tabular}{|c|c|}
\hline Strain & Plasmid content \\
\hline $39-5$ & $\begin{array}{l}\text { pPD1, pPD2, pPD3, } \\
\text { pPD4, pPD5, pPD6 }\end{array}$ \\
\hline JH2SS & None \\
\hline JH2-2 & None \\
\hline OG $1-10$ & None \\
\hline OG1-RF1 & None \\
\hline OG $1-30$ & pAD1::Tn917(Em) \\
\hline OG1-31 & pOB 1 \\
\hline OG1-32 & pPDI \\
\hline YA101 & $\mathrm{pAM} \gamma 1, \mathrm{pAM} \alpha 1$ \\
\hline YA102 & $\mathrm{pAM} \gamma 2, \mathrm{pAM} \alpha 1$ \\
\hline YA103 & $\mathrm{pAM} \gamma 3, \mathrm{pAM} \alpha 1$ \\
\hline DT11 & $\mathrm{pAM} \alpha \mathrm{l}$ \\
\hline
\end{tabular}

\author{
Comments and references
}

A haemolytic strain from subgingival scrapings of a patient with periodontitis (Rosan \& Williams, 1964).

Resistant to streptomycin and spectinomycin (Franke \& Clewell, 1981). Resistant to rifampin and fusidic acid. Derivative of $\mathrm{JH} 2$

(Jacob \& Hobbs, 1974).

Streptomycin resistant (Dunny et al., 1978).

Rifampin, fusidic acid resistant. Mutant of OG1. (Dunny et al., 1979).

Transconjugant from a mating between JH2-2 (pAD $1:$ : Tn917) and

OG1-10. pAD1 : :Tn917 had been derived as previously reported (Tomich et al., 1980).

OG1-RF1 transconjugant from mating with 5952 (Dunny et al., 1979). OG1-10 transconjugant from mating with 39-5.

JH2-2 transconjugant. Plasmids were from DS5C1 (Clewell et al., 1982). pAM $\alpha 1$ is a non-conjugative $6 \mathrm{Mdal}$ plasmid encoding tetracycline resistance.

JH2-2 transconjugant. Plasmids were from DS5C1 (Clewell et al., 1982). JH2SS transconjugant. Plasmids were from DS5C1 (Clewell et al., 1982). A JH2-2 transconjugant (Dunny \& Clewell, 1975).

different classes of plasmids cross-reacts immunologically with antiserum raised against the aggregation substance synthesized by cells harbouring pPD1.

\section{METHODS}

Bacteria and media. The bacterial strains used in this study are listed in Table 1. Streptococcus faecalis strain 39-5, the primary strain used in this study, is a haemolysin-bacteriocin-producing strain originally given to us by $B$. Rosan (University of Pennsylvania). Media used were N2GT (Dunny et al., 1979) [Oxoid nutrient broth no. 2 supplemented with Tris buffer ( $\mathrm{pH} 7.0)$ and glucose $(0.2 \%$ w/v)] or Difco Brain-Heart Infusion. Streptococcus faecalis strains harbouring the various plasmids were constructed in 4 or $18 \mathrm{~h}$ matings in broth or on filters as previously described (Franke \& Clewell, 1981). Pheromone assays of culture filtrates were as previously described (Dunny et al., 1979).

Reagents and enzymes. These materials and their sources were as follows: Zwittergent 3-12, $N$-acetyl Dgalactosamine, $N$-acetyl D-glucosamine, L-fucose, pronase, lysozyme and lipase (pancreatic) from Calbiochem; trypsin from Sigma; glutaraldehyde, D-glucose and D-lactose from Baker (Phillipsburg, New Jersey); horseradish peroxidase-conjugated goat anti-rabbit IgG from Cappel Labs (Downingtown, Pa., U.S.A.); fluorescein-labelled goat anti-rabbit IgG from Sylvania (Millburn, N.J., U.S.A.); D-galactose, D-mannose and fluorescent antibody mounting fluid from Difco. Restriction enzymes used in the mapping of pPD1 were obtained from Bethesda Research Laboratories (Gaithersburg, Md., U.S.A.). Seakem HGT agarose, used in crossed immunoelectrophoresis, was from Marine Colloids Inc. (Rockland, Me., U.S.A.).

Bacteriocin assays. Strain JH2-2 was used as an indicator strain. The bacteriocin activity associated with pPD5 was easily detected using a previously reported procedure involving stabs of producer strains into soft agar overlays containing the indicator strain (Franke \& Clewell, 1981). The bacteriocin associated with pPD1 was not as easily resolved by this method. In this case, plates containing fresh colonies of cells harbouring pPDI (but not pPD5) were overlayed with soft $(0.75 \%)$ agar containing the indicator strain. Zones of inhibition were visible after overnight incubation at $37^{\circ} \mathrm{C}$.

Isolation and electrophoretic analysis of plasmid DNA. Plasmid DNA from strains 39-5 and DS16 was prepared as follows. Cells grown to mid-exponential or stationary phase in $250 \mathrm{ml}$ of Brain-Heart Infusion medium were harvested, washed with TES $\left(0.03 \mathrm{M}\right.$-Tris, $0.005 \mathrm{M}-\mathrm{Na}_{2}$ EDTA, $\left.0.05 \mathrm{M}-\mathrm{NaCl}\right)$ and resuspended in $15 \mathrm{ml}$ of $25 \%$ glucose in TES. Lysozyme [ $5 \mathrm{ml}$ of an $8 \mathrm{mg} \mathrm{m}^{-1}$ solution in TES/glucose $(25 \%)$ ] was added and the suspension was allowed to incubate at $37^{\circ} \mathrm{C}$ for $1 \mathrm{~h}$. The cells were then lysed by the addition of $1 \cdot 1 \mathrm{ml}$ of $20 \%(\mathrm{w} / \mathrm{v}$ ) SDS (in TES); the container was inverted several times to obtain uniform mixing. Six ml of $5 \mathrm{M}-\mathrm{NaCl}$ was then added; the lysate was kept on ice for $3 \mathrm{~h}$, after which it was centrifuged at 20000 r.p.m. $\left(4^{\circ} \mathrm{C}\right.$ ) for $1 \mathrm{~h}$ in the SS34 (Sorvall) rotor to remove chromosomal DNA selectively. The supernatant was then removed, mixed with 2 vol. ethanol and placed at $-70^{\circ} \mathrm{C}$ for $40 \mathrm{~min}$. The precipitated DNA was collected by centrifugation at 5000 r.p.m. (SS34 rotor), dried in a desiccator for $15 \mathrm{~min}$ and redissolved in TES. The sample was then centrifuged to equilibrium in an ethidium bromide/CsCl buoyant density gradient (Beckman, 50Ti rotor) as previously described (Franke \& Clewell, 1981). The plasmid band was removed by needle and syringe from the side of the tube and recentrifuged as before. Plasmid DNA was then removed (as before), dialysed against SSC $(0.05 \mathrm{M}-\mathrm{NaCl}, 0.015 \mathrm{M}$-sodium citrate, $\mathrm{pH} 7 \cdot 3)$ 
and then concentrated by ethanol precipitation (Franke \& Clewell, 1981) and resuspended in $50 \mathrm{~mm}-\mathrm{Tris} \mathrm{pH} 7 \cdot 2$. Plasmid DNA was then analysed by agarose gel electrophoresis as previously described (Franke \& Clewell, 1981). Plasmid DNAs from S. faecalis strain DS16 (Tomich et al., 1979) and Escherichia coli strain VA517 (Macrina et al., 1978) (generously supplied by F. Macrina), were used as molecular weight markers.

The isolation of pPDI for the purpose of restriction mapping, the electrophoresis procedures, and strategy used in restriction mapping were similar to those reported elsewhere for pADI (Franke \& Clewell, 1981; Franke, 1980).

Preparation of induced-dissociated cells. A culture $(10 \mathrm{ml})$ of responder cells was grown to mid-exponential phase (70 Klett Units, using the no. 54 filter, on a Klett-Summerson colorimeter). Filtered supernatant ( $5 \mathrm{ml}$; Millipore $0.22 \mu \mathrm{m}$ ) of a culture of $\mathrm{JH} 2-2$ containing cPD1 (pheromone) was added. Using 39-5 cells as responders, the filtrate showed a cPDI activity with a titre of 64 . After incubation for $40 \mathrm{~min}$, significant clumping generally occurred. The cells were then dissociated by the addition of EDTA ( $25 \mathrm{mM}, \mathrm{pH} 7 \cdot 0)$, sedimented, washed with $30 \mathrm{~mm}$-Tris $(\mathrm{pH} \mathrm{7.0)}$ and resuspended in $5 \mathrm{ml}$ of the same buffer. The cells remained well suspended (i.e. dissociated) in this state.

Enzyme-treatment of induced-dissociated cells. Dissociated cells ( $1 \mathrm{ml}$ in each case) were treated in the following ways: trypsin $\left(20 \mu \mathrm{g} \mathrm{ml}^{-1}\right)$ in $30 \mathrm{~mm}$-Tris, $\mathrm{pH} 8 \cdot 0$, for $20 \mathrm{~min}$; pronase $\left(20 \mu \mathrm{g} \mathrm{ml}^{-1}\right)$ in $30 \mathrm{~mm}$-Tris, $\mathrm{pH} 7 \cdot 0$, for $20 \mathrm{~min}$; lysozyme $\left(100 \mu \mathrm{g} \mathrm{ml}^{-1}\right)$ in $30 \mathrm{mM}$-Tris, $\mathrm{pH} 7.0$ for $20 \mathrm{~min}$; lipase $\left(10 \mu \mathrm{g} \mathrm{ml}^{-1}\right)$ in $1 \mathrm{~mm}-\mathrm{CaCl}_{2}, 30 \mathrm{~mm}-\mathrm{Tris}$, $\mathrm{pH} 7.0$ for $20 \mathrm{~min}$. After treatment, the cells were washed twice by centrifugation in $30 \mathrm{~mm}$-Tris and suspended in $1 \mathrm{ml} 30 \mathrm{~mm}$-Tris: $\mathrm{CaCl}_{2}$ (to $0 \cdot 1 \mathrm{~mm}$ ) and phosphate (to $20 \mathrm{~mm}$ ) were then added.

Preparation of antiserum against induced $39-5$ cells. A $30 \mathrm{ml}$ mid-exponential phase culture of pheromone-induced 39-5 cells was harvested and washed in PBS $\left(0 \cdot 14 \mathrm{M}-\mathrm{NaCl}, 1.5 \mathrm{~mm}-\mathrm{KH}_{2} \mathrm{PO}_{4}, 2 \cdot 7 \mathrm{~mm}-\mathrm{KCl}, \mathrm{pH} 7 \cdot 4\right)$. The cells were resuspended in $2 \mathrm{ml}$ PBS and fixed with $0.5 \%(\mathrm{w} / \mathrm{v})$ glutaraldehyde at $37^{\circ} \mathrm{C}$ for $1 \mathrm{~h}$; they were then washed several times by centrifugation with PBS. After obtaining pre-immunization serum, approximately $10^{4}$ cells were injected intramuscularly into each rabbit four times over a period of $10 \mathrm{~d}$ at $2 \mathrm{~d}$ intervals and then again at $30 \mathrm{~d}$ and $37 \mathrm{~d}$. Two weeks later, the rabbits were bled from the marginal ear veins. In some experiments, sera $(2 \mathrm{ml})$ were absorbed twice at $37^{\circ} \mathrm{C}$ for $20 \mathrm{~min}$ with uninduced $39-5$, JH2-2 and OG 1-30 cell pellets (from $250 \mathrm{ml}$ midexponential cultures). Cells were removed by centrifugation.

Fluorescent-antibody staining. Ten $\mu \mathrm{l}$ of cell suspension (approximately $10^{8}$ cells $\mathrm{ml}^{-1}$ in PBS) was placed on a glass microscope slide and air-dried. The cells were heat-fixed by two passages through a flame. The fixed specimens were covered with $10 \mu \mathrm{l}$ of a series of twofold dilutions of antisera and were incubated at room temperature in a moist chamber for $1 \mathrm{~h}$. Following three washes with PBS, the slides were flooded with a $1: 20$ dilution of fluorescein-labelled goat anti-rabbit IgG. After incubation for $1 \mathrm{~h}$ at room temperature, they were washed three times with PBS and then counterstained with eriochrome black solution. Finally, a drop of buffered glycerol saline mounting fluid ( $\mathrm{pH} \mathrm{7-5)} \mathrm{and} \mathrm{a} \mathrm{cover} \mathrm{slip} \mathrm{was} \mathrm{placed} \mathrm{on} \mathrm{the} \mathrm{stained} \mathrm{specimen.} \mathrm{The} \mathrm{slides} \mathrm{were} \mathrm{then}$ examined with a microscope equipped with transmission UV illumination.

Horseradish peroxidase staining of 39-5 cells. Immunoelectron microscopy employing horseradish peroxidaselabelled goat anti-rabbit IgG was as described by Lai et al. (1975). Prior to staining with labelled antibody, 39-5 cells, uninduced or induced by $\mathrm{CPDl}$, were incubated with antiserum against induced 39-5 cells which had previously been absorbed with uninduced $39-5$ cells. (Absorbed antiserum no longer reacted with uninduced cells as determined by indirect immunofluorescence). The final preparations were examined in a Hitachi HS- 8 electron microscope.

Crossed immunoelectrophoresis. Crossed immunoelectrophoresis was carried out using a modification (Clark \& Freeman, 1967) of the method of Laurell (1965). Barbital/ $\mathrm{HCl}$ buffer $(2.5 \mathrm{~mm}, \mathrm{pH} 8.6)$ was used throughout the system. One percent agarose in buffer was cast on glass plates $(50 \mathrm{~mm} \times 50 \mathrm{~mm})$ to give a volume to surface area ratio of $0.132 \mathrm{ml} \mathrm{cm}^{-2}$. Pheromone (cPDl)-induced and uninduced cells of strain 39-5 (approximately $0.2 \mathrm{~g}$ dry weight of each) were extracted with $10 \mathrm{ml} 0 \cdot 2 \%$ Zwittergent 3-12 (ZW312) in PBS. First dimension electrophoresis of $5 \mu$ of each extract was carried out at $6 \mathrm{~V} \mathrm{~cm}^{-1}$ for $45 \mathrm{~min}$. Second dimension electrophoresis into agarose containing anti-induced $39-5$ immunoglobulins $\left(75 \mu \mathrm{ml}^{-1}\right)$ was at $2 \mathrm{~V} \mathrm{~cm}^{-1}$ for $16 \mathrm{~h}$. The antiinduced 39-5 immunoglobulin fraction was prepared as described by Harboe \& Ingild (1973), omitting the DEAEcellulose chromatography step. The final volume of this fraction was one-third that of the original serum pool. All gels were alternately pressed and washed twice with $0 \cdot 1 \mathrm{M}-\mathrm{NaCl}$. After a final press, brief wash with a stream of distilled water and drying, they were stained with Coomassie blue R-250 (Weeke, 1973).

\section{RESULTS}

\section{Plasmid content of $S$. faecalis strain 39-5}

As shown in Table 2, strain 39-5 harboured at least six plasmids (pPD1, 2, 3, 4, 5, and 6) ranging in mass from 3.4 to $38.5 \mathrm{MDal}$. Haemolytic-negative derivatives obtained at a frequency of $2 \%$ after growth overnight in the presence of the curing agent novobiocin 
Table 2. Plasmids in Streptococcus faecalis strain 39-5

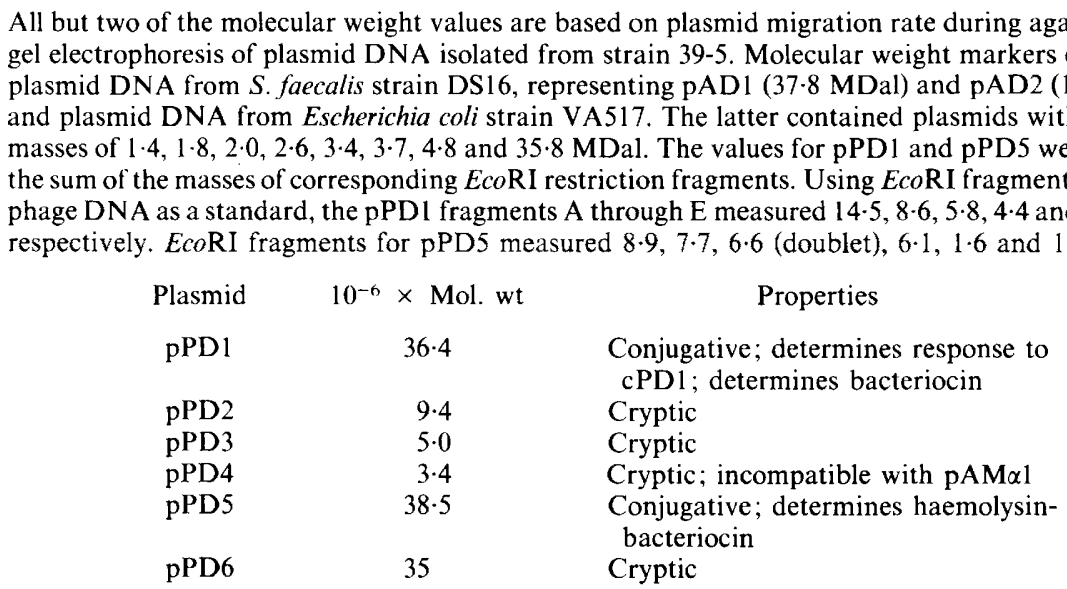

( $5 \mu \mathrm{g} \mathrm{ml}^{-1}$ ) were devoid of pPD5. Haemolytic transconjugants arising from matings between $39-$ 5 and the plasmid-free strain JH2-2 or JH2SS were found to harbour pPD5 or both pPD5 and pPD1. Cured, haemolytic-negative derivatives of the latter type carried only pPD1; these cells were found to produce a bacteriocin. We thus concluded that haemolysin activity is determined by pPD5, whereas a bacteriocin activity is conferred by pPD1. However, pPD5 also conferred a bacteriocin activity which was independent of that determined by pPD1, and it is likely that the haemolysin and bacteriocin activities represent the same protein, as in other haemolysinbacteriocin systems in S. faecalis (Brock \& Davie, 1963; Granato \& Jackson, 1969). The frequent cotransfer of pPD1 and pPD5 and the inability to resolve these two plasmids by sedimentation analysis led to the earlier erroneous belief (Dunny et al., 1978) that haemolysin was determined by pPD1.

Both pPD1 and pPD5 were capable of independent conjugation but, while transconjugants harbouring only pPD1 exhibited a characteristic clumping response, strains with only pPD5 were unresponsive. Filtrates of cells carrying only pPD1 did not induce $39-5$ cells to clump, whereas filtrates from strains with pPD5 alone exhibited a pheromone titre similar to that of filtrates from an isogenic plasmid-free strain (about 64-128). The tetracycline resistance element Tn916 was introduced on to both pPD1 and pPD5 by a method described elsewhere (Franke \& Clewell, 1981); the resistance marker facilitated the quantification of conjugation frequencies. The ability of pPD1 to confer an aggregation response correlates with its ability to transfer efficiently in broth ( $\geq 10^{-2}$ per donor); however, cells harbouring pPD5 alone (no aggregation response) did not transfer plasmid well in broth $\left(<10^{-5}\right)$, yet transfer occurred efficiently if matings were performed on filter membranes $\left(\geq 10^{-4}\right)$.

Despite the presence of several other plasmids in strain $39-5$, the aggregation response exhibited by this strain appeared to relate only to pPD1. (The related pheromone is referred to as cPD1.) The possibility, however, that 39-5 cells have the potential to respond to pheromones other than cPD1, has not been completely ruled out. Conceivably, pPD1 could affect production of pheromones other than cPD1 and, while pPD5 did not express a detectable aggregation response in a different host, it is possible that because of different host influences, it could control a response in the 39-5 background. It is also possible that pPD5, and even pPD6, could have pheromone-response systems that are suppressed in the presence of other plasmids (e.g. pPD1). Construction of strains having different combinations of these plasmids in the 39-5 background could lead to further insight into these possibilities, although the lack of selectable markers makes this a laborious task. Streptococcus faecalis strain DS5 was recently shown to harbour three plasmids that encoded three specific pheromone responses (Clewell et al., 1982).

A restriction map of pPD1 is shown in Fig. 1. The restriction map has no resemblance to that of the recently mapped pheromone-plasmid, pADl (Clewell, 1981; Franke, 1980). 


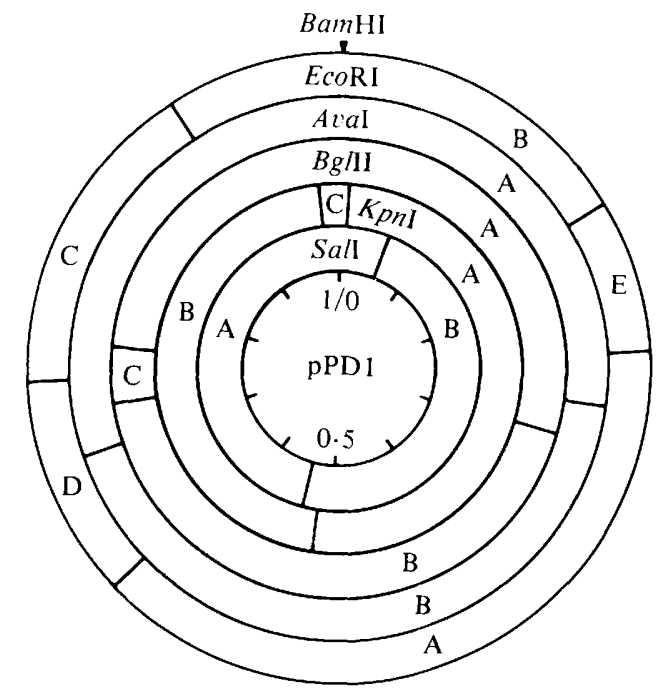

Fig. 1. Restriction map of pPD1. Plasmid DNA (pPD1) isolated from $S$. faecalis strain OG1-32 was mapped with respect to sites cleaved by BamHI, EcoRI, AvaI, BgIII, KpnI and SalI. Mapping was based on double and partial digestion analyses using appropriate enzymes. The fragments were named alphabetically according to size, beginning with the largest fragments. The single BamHI site was arbitrarily taken to mark the beginning and end of the map.

Table 3. Phosphate and calcium ion concentrations required for aggregation of induced 39-5 cells +, Aggregation; -, no aggregation.

(a) Phosphate

$\mathrm{Na}_{2} \mathrm{HPO}$
(mM)
0
0
1
5
20

$$
\underset{(\mathrm{mM})}{\mathrm{CaCl}_{2}}
$$

0
$0 \cdot 1$
$0 \cdot 1$
$0 \cdot 1$
$0 \cdot 1$

Aggregation

-
-
-
+
+

(b) Calcium

$\underset{(\mathrm{mM})}{\mathrm{Na}_{2} \mathrm{HPO}_{4}} \underset{(\mathrm{mM})}{\mathrm{CaCl}_{2}}$

0

0

$0 \cdot 05$

$0 \cdot 1$

0.5

0
20
20
20
20

Aggregation

No information is available with regard to determinants on the other plasmids in $39-5$. Transconjugants harbouring pPD1 or pPD5 (or both) occasionally also carried the small cryptic plasmid pPD4. The latter was probably mobilized by one (or both) of the larger plasmids. pPD4 was incompatible with the small (6.0 MDal) tetracycline-resistance plasmid pAM $\alpha 1$ of strain DS5 (Clewell et al., 1975). Mobilization of pAM $\alpha 1$ into 39-5S, a streptomycin-resistant mutant of 39-5, always resulted in the loss of pPD4 (data not shown).

\section{Requirements for aggregation}

The large aggregates of 39-5 cells that arose upon induction with a filtrate of $\mathbf{J H} 2-2$ (plasmidfree) were readily dissociated with $25 \mathrm{~mm}$-EDTA. If dissociated cells were pelleted, washed and resuspended in buffer $(0.03 \mathrm{M}$-Tris, $\mathrm{pH} \mathrm{7.0)}$, reaggregation did not occur. As shown in Table 3 , reaggregation required a minimum of $5 \mathrm{mM}$-phosphate and $0.1 \mathrm{mM}^{-\mathrm{CaCl}_{2}}$. In place of calcium ions, $\mathrm{Mg}^{2+}, \mathrm{Mn}^{2+}$, or $\mathrm{Co}^{2+}$ also promoted aggregation. Studies on the effect of $\mathrm{pH}$ on aggregation led to the surprising observation that phosphate and divalent cations were not required for reaggregation if the $\mathrm{pH}$ was lowered to 2.5 (an aqueous cell suspension adjusted with $\mathrm{HCl}$ ). The range in which this type of clumping was observed was $\mathrm{pH} 2 \cdot 0-3 \cdot 0$. The fact that uninduced cells failed to aggregate at the low $\mathrm{pH}$ and that $39-5$ cells pre-exposed to a filtrate of JH2-2(pPD1) (i.e., a strain which does not excrete cPD1) also failed to aggregate at this pH implied this phenomenon was specifically related to a $\mathrm{cPD} 1$-induced response. 

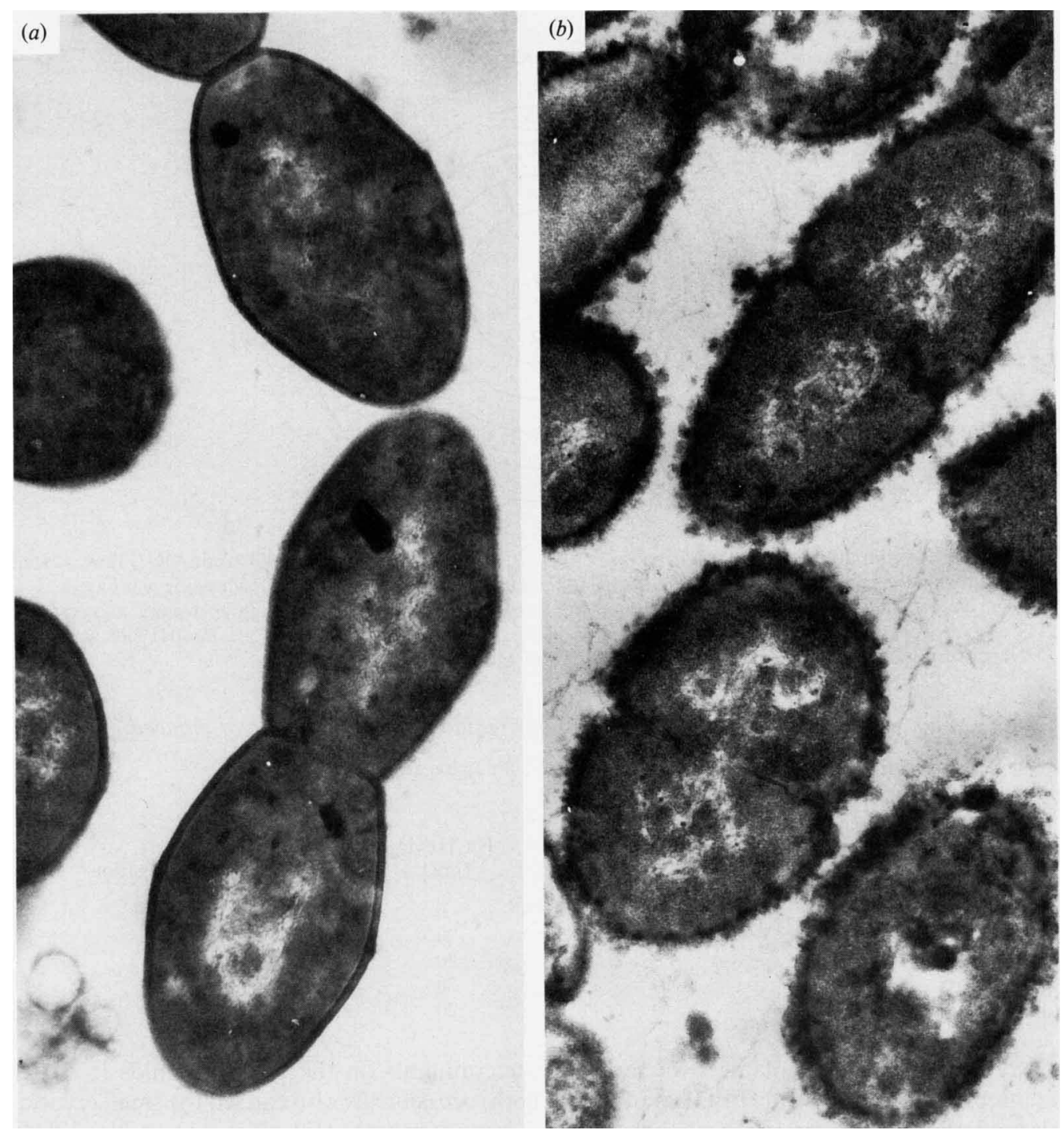

Fig. 2. New surface antigen appearing on the surface of pheromone-induced $S$. faecalis $39-5$ cells. The immunoelectron microscopic procedure employed a peroxidase stain as described in Methods. (a) Uninduced cells: $(b)$ induced cells.

\section{Biochemical properties}

To examine the nature of the cell surface component involved in aggregation, dissociated cells were subjected to various conditions known to alter macromolecular structure. Exposure to trypsin, pronase, $\operatorname{SDS}[0.05 \%(\mathrm{w} / \mathrm{v}), 30 \mathrm{~min}], \mathrm{LiCl}(4 \mathrm{M}, 90 \mathrm{~min})$ or heat $\left(98^{\circ} \mathrm{C}, 5 \mathrm{~min}\right)$ destroyed the ability of the cells to reaggregate, whereas treatment with lysozyme, lipase, or glutaraldehyde $[0.5 \%(\mathrm{w} / \mathrm{v}), 30 \mathrm{~min}]$ had no effect. Similar results were obtained when the treated cells were exposed to $\mathrm{pH} 2.5$ in the absence of phosphate and calcium ions. These data imply that aggregation substance is a protein.

Because the adherence of certain Gram-negative bacteria to specific tissues involves binding to a carbohydrate moiety and because such adherence may be inhibited in the presence of 
Table 4. Binding of antiserum against induced 39-5 cells to strains harbouring different plasmids and induced by different pheromones

\begin{abstract}
The titre was determined by fluorescent-antibody staining (see Methods). Rabbit antiserum was prepared against pheromone-induced $39-5$ and was subsequently absorbed by uninduced $39-5$ cells as well as OGIS and JH2SS (see Methods).
\end{abstract}

Strain (relevant plasmid)

39-5 (pPD1 through pPD6)

OG1-30 (pAD1:: Tn917)

OG1-31 (pOB1)

OG1-32 (pPD1)

YA101 (pAM $\gamma 1$, pAM $\alpha 1)$

YA102 (pAM $\gamma 2, \mathrm{pAM} \alpha 1)$

YAl03 (pAM $\gamma 3$, pAM $\alpha 1)$

JH2-2 (pAM $\alpha 1$ )

\begin{tabular}{|c|c|}
\hline \multicolumn{2}{|c|}{ Titre } \\
\hline Uninduced & Induced \\
\hline$<1$ & 160 \\
\hline$<1$ & 40 \\
\hline$<1$ & 40 \\
\hline$<1$ & 80 \\
\hline$<1$ & 40 \\
\hline$<1$ & 40 \\
\hline$<1$ & 20 \\
\hline$<1$ & $<1$ \\
\hline
\end{tabular}

specific sugars (Jones, 1977), we examined the effect of sugars on reaggregation. The following sugars all had no effect on reaggregation if present with phosphate and calcium ions: D-lactose $(0.05 \mathrm{M})$, D-galactose ( $0.05 \mathrm{M})$, sucrose (0.02 M), D-glucose (0.05 M), D-mannose ( $0.05 \mathrm{M})$, L-fucose $(0.05 \mathrm{M})$ and a mixture of D-galactose, $N$-acetyl D-galactosamine and $N$-acetyl D-glucosamine (each at a concentration of $0.002 \mathrm{M}$ ).

\title{
Immunoelectron microscopic analyses
}

Using a preparation of induced 39-5 cells that were dissociated with EDTA and fixed with glutaraldehyde, we prepared a rabbit antiserum which reacted readily in an indirect immunofluorescence assay with induced cells (titre 4096) as well as uninduced cells (titre 1024). Antisera absorbed with uninduced cells no longer reacted with uninduced cells, but had a titre of 80-160 against induced cells. This serum was used in an immunoelectron microscopic examination of induced and uninduced 39-5 cells. Figure 2 shows the surface of uninduced cells to be relatively 'clean', whereas induced cells exhibited an amorphous material, presumably representing aggregation substance, coating their surface. It is conceivable that this represents a microfibrillar substance, although fibrillae, per se, were not clearly resolved here. Earlier studies using negative-staining techniques as well as scanning electron microscopy, found no detectable differences between induced and uninduced cells (Dunny, 1978).

\section{Similarities of aggregation substance associated with different conjugative plasmids}

Table 4 shows that antiserum specifically prepared against induced 39-5 cells cross-reacted readily with the aggregation substance induced in strains harbouring different conjugative plasmids. pAM $\gamma 1, \mathrm{pAM} \gamma 2$ and $\mathrm{pAM} \gamma 3$ make use of pheromones distinct from $\mathrm{cPD} 1$ and from each other (Clewell et al., 1982; R. Craig, personal communication). pAM $\gamma 1$ and pAD1, however, make use of the same pheromone (Clewell et al., 1982). The pOB1 plasmid responds to a pheromone (COB1) distinct from $\mathrm{CADl}$ and $\mathrm{CPD} 1$ (R. Craig, personal communication); its relationship to pAM $\gamma 2$ and $\mathrm{pAM} \gamma 3$, however, has not been tested. Because of the significant degree of cross-reaction observed in all cases, it would appear that, despite differences in pheromone specificity, the aggregation substances have significant structural similarity.

\section{Extraction of aggregation substance and detection by crossed immunoelectrophoresis}

A substance was extracted from induced, but not uninduced, 39-5 cells which was readily detectable by the method of crossed immunoelectrophoresis. The data of Fig. 3 illustrate the use of an unabsorbed antiserum which gave rise to several immunoprecipitate arcs. A prominent immunoprecipitate is seen in the case of the extract from induced, but not uninduced cells. 


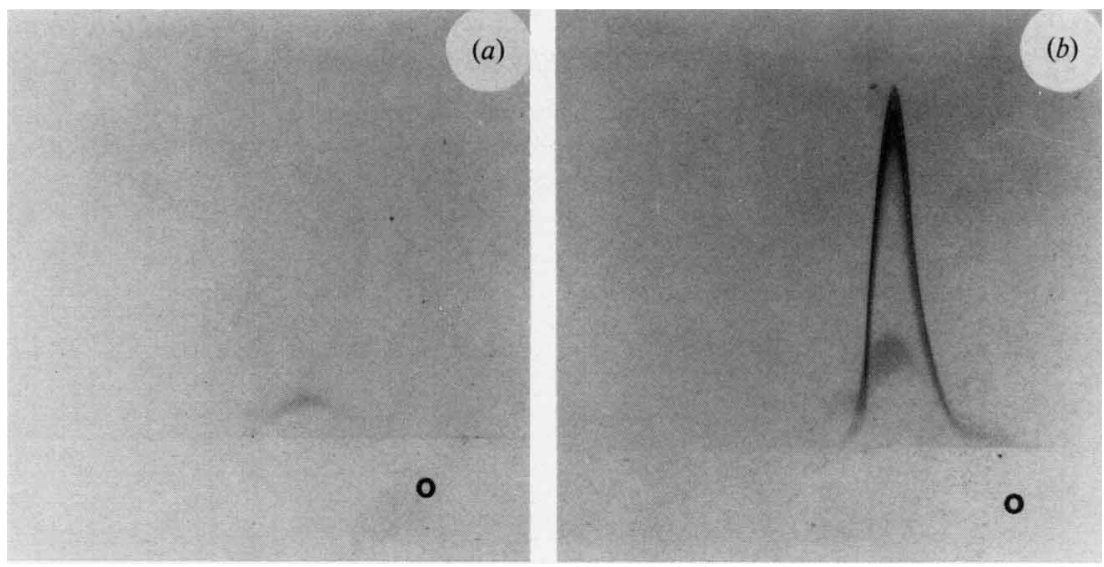

Fig. 3. Crossed immunoelectrophoresis of extracts of $S$. faecalis 39-5 cells. Zwittergent 3-12 extracts $(5 \mu l)$ of uninduced cells $(a)$ and induced cells $(b)$ were placed in sample wells of minimal diameter (marked by circles in the lower right-hand corners). Electrophoresis at $6 \mathrm{~V} \mathrm{~cm}^{-1}$ for $45 \mathrm{~min}$ was carried out with the anode to the left. Second dimension electrophoresis with the anode at the top was into agarose containing a concentrated immunoglobulin preparation $\left(75 \mu 1 \mathrm{ml}^{-1}\right.$; see Methods).

\section{DISCUSSION}

Streptococcus faecalis strain $39-5$ has been shown to harbour six plasmids. Three of the plasmids, pPD1, pPD5 and pPD6, are relatively large in size, and at least two of these, pPD1 and pPD5, are conjugative. Only pPD1, however, appeared to control the pheromone-induced appearance on the cell surface of a proteinaceous macromolecular substance with unique immunological properties. Believed to represent aggregation substance, this material was found to be immunologically similar to the aggregation substance induced in different plasmid systems responding to different sex pheromones.

Phosphate and divalent cations were required for aggregation. It is interesting, however, that these factors were not necessary at $\mathrm{pH} 2 \cdot 5$. At physiological pHs the phosphate and divalent cations may act to stabilize the conformation of aggregation substance or its receptor and/or modulate the repulsive effects of neighbouring cell surface molecules. The net negative charge on the bacterial surface may be significantly reduced at $\mathrm{pH} 2 \cdot 5$. It is not likely that there is any physiological significance to aggregation at this low $\mathrm{pH}$.

The location of the structural gene(s) for aggregation substance remains to be determined. It could reside on either the plasmid or a plasmid-controlled chromosomal locus. A characterization of the pPD1-related aggregation substance is in progress (Kessler et al., 1982; R. E. Kessler \& Y. Yagi, unpublished observations) and the use of specific antiserum has been, and will continue to be, extremely useful in monitoring aggregation substance in the course of purification and subsequent analyses. Studies on the structure of aggregation substance and the nature of its binding to the, as yet, unidentified 'binding substance' should lead to a better understanding of the biochemical processes involved in pheromone-induced conjugation in $S$. faecalis.

This work was supported by Public Health Service Grants DEO2731 and A110318 from the National Institutes of Health. J.H.S. was supported by a predoctoral training grant (genetics) and D. B.C. was the recipient of Research Career Development Award AI00061, both from the National Institutes of Health. We thank B. Brown and R. Craig for technical assistance and helpful discussions

\section{REFERENCES}

Brock, T. D. \& Davie, J. M. (1963). Probable identity of a group D hemolysin with a bacteriocin. Journal of Bacteriology 86, 708-712.

Clarke, H. \& Freeman, T. A. (1967). A quantitative immunoelectrophoresis method. In Protides of the Biological Fluids, vol. 14, pp. 503-509. Edited by H. Peters. Amsterdam: Elsevier.

Clewell, D. B. (1981). Plasmids, drug resistance, and 
gene transfer in the genus Streptococcus. Microbiological Reviews 45, 409-436.

Clewell, D. B. \& Brown, B. (1980). Sex pheromone cADl in Streptococcus faecalis: induction of a function related to plasmid transfer. Journal of Bacteriology 143, 1063-1065.

Clewell, D. B., Yagi, Y. \& Bauer, B. (1975). Plasmid determined tetracycline resistance in Streptococcus faecalis. Evidence for gene amplification during growth in the presence of tetracycline. Proceedings of the National Academy of Sciences of the United States of America 72, 1720-1724.

Clewell, D. B., Yagi, Y., Ike, Y., Craig, R. A., Brown, B. L. \& AN, F. (1982). Sex pheromones in Streptococcus faecalis. Multiple pheromone systems in strain DS5, similarities of pAD1 and pAM $\gamma 1$, and mutants of $\mathrm{pADl}$ altered in conjugative properties. In Microbiology-1982, pp. 97-100. Edited by D. Schlessinger. Washington, D.C.: American Society for Microbiology.

DUNNY, G. (1978). Gene transfer in Streptococcus faecalis: conjugation, mating aggregates, and sex pheromones. Ph.D. thesis, University of Michigan, U.S.A.

Dunny, G. \& Clewell, D. (1975). Transmissible toxin (hemolysin) plasmid in Streptococcus faecalis and its mobilization of a noninfectious drug resistance plasmid. Journal of Bacteriology 124, 784-790.

Dunny, G., Brown, B. \& Clewell, D. B. (1978). Induced cell aggregation and mating in Streptococcus faecalis. Evidence for a bacterial sex pheromone. Proceedings of the National Academy of Sciences of the United States of America 75, 3479-3483.

Dunny, G. M., Craig, R., Carron, R. \& Clewell, D. B. (1979). Plasmid transfer in Streptococcus faecalis. Production of multiple sex pheromones by recipients. Plasmid 2, 454-465.

FRANKE, A. (1980). A tetracycline resistance transposon (Tn916) in Streptococcus faecalis: transposition and conjugal transfer. Ph.D. thesis, University of Michigan, U.S.A

Franke, A. \& Clewell, D. B. (1981). Evidence for a chromosome-borne resistance transposon in Streptococcus faecalis capable of "conjugal" transfer in the absence of a conjugative plasmid. Journal of Bacteriology 145, 494-502.

Granato, P. A. \& Jackson, R. W. (1969). Biocomponent nature of lysin from Streptococcus zymogenes. Journal of Bacteriology 100, 865-868.
Harboe, N. \& INGILD, A. (1973). Immunization, isolation of immuno-globulins, estimation of antibody titer. Scandinavian Journal of Immunology 2 (Suppl. 1), 161-164.

JACOB, A. \& HoBBS, S. J. (1974). Conjugal transfer of plasmid-borne multiple antibiotic resistance in Streptococcus faecalis var. zymogenes. Journal of Bacteriology 117, 360-372.

JONES, G. W. (1977). The attachment of bacteria to the surfaces of animal cells. In Microbial Interactions, Series B. Receptors and Recognition, vol. 3, pp. 139 176. Edited by J. L. Reissig. London: Chapman \& Hall.

Kessler, R. E., YaGi, Y. \& Clewell, D. B. (1982). Identification and partial purification of a surface antigen of Streptococcus faecalis that is synthesized during pheromone-induced aggregation. In Microbiology-1982, pp. 101-102. Edited by D. Schlessinger. Washington, D.C.: American Society for Microbiology.

Lai, C., Listgarten, M. A. \& Rosan, B. (1975). Immunoelectron microscopic identification and localization of Streptococcus sanguis with peroxidaselabeled antibody: localization of surface antigens in pure cultures. Infection and Immunity 2, 193-199.

LaUrell, C. (1965). Antigen-antibody cross immunoelectrophoresis. Analytical Biochemistry 10, 358-361.

Macrina, F. L., Kopecko, D. J., Jones, K. R., Ayers, D. J. \& MCCowan, S. M. (1978). A multiple plasmid-containing Escherichia coli strain: convenient source of size reference plasmid molecules. Plasmid 1, 417-420.

Rosan, B. \& Williams, N. (1964). Hyaluronidase production by oral enterococci. Archices of Oral Biology 9, 291-298.

Tomich, P., AN, F., Damle, S. \& Clewell, D. (1979). Plasmid-related transmissibility and multiple drug resistance in Streptococcus faecalis subsp. zymogenes strain DS16. Antimicrobial Agents and Chemotherapy 15, 828-830.

Tomich, P., AN, F. \& Clewell, D. B. (1980). Properties of erythromycin-inducible transposon Tn917 in Streptococcus faecalis. Journal of Bacteriology 141, 1366-1374.

WEEKE, B. (1973). Crossed immunoelectrophoresis. Scandinatian Journal of Immunology 2 (Suppl. 1), 4756. 